\title{
ENVIRONMENTAL IMPACT OF USING AQUEOUS EXTRACTS OF SOME AGRICULTURE RESIDUES AND THEIR EFFECTS ON GROWTH, YIELD AND SOME YIELD COMPONENTS OF SOME PLANTS
}

Hamed, Mervat A. ; Wafaa A. Hafez and Shreen S. Ahmed

Soils, Water and Environment Res. Institute, ARC, Giza, Egypt

\begin{abstract}
There is a great need for intensifying agricultural production in Egypt. In this respect, an attempt was done to determine the effects of plant extracts from some agricultural residues such as rice straw, Bagasse, and soybean meal when applied with or without nitrogen mineral fertilizers on growth parameters, chemical components and yield of wheat and barley plants. Two experiments (pot and field) were carried out at Giza, Agricultural Research Station, during winter season of 2010/2011. Results of pot experiment confirmed that the growth parameters of wheat plants affected by applied of aqueous agricultural residues extracts such as shoot length and dry weight compared to control treatment (treated with recommended dose of mineral fertilizer only). The field experiment demonstrated that among the extracts tested, $100 \%$ rice straw extract follows by $50 \%$ bagasse with $50 \%$ nitrogen mineral fertilizer were highly effective on yield relative to mineral fertilizer only as a control. Regarding to the chemical and biochemical parameters, the highest values of nitrogen and potassium $\%$ were recorded in treatment of $25 \%$ soyabean meal extract with $75 \%$ nitrogen compared to control. Phosphorus content showed increasing at $25 \%$ mixture of different extract with $75 \%$ nitrogen mineral fertilizer treatment. The highest value of crude protein was observed at treatment of $25 \%$ soyabean meal extract with $75 \%$ nitrogen mineral fertilizer followed by $25 \%$ rice straw extract with $75 \%$ nitrogen mineral fertilizer compared to control. The highest value of total carbohydrate was observed in treatment of $100 \%$ bagasse extract, followed by $100 \%$ mixture of different extract treatment then $50 \%$ rice straw extract with $50 \%$ nitrogen mineral fertilizer compared to control, respectively. The highest value of Indole acetic acid (IAA) was recorded in treatment of $100 \%$ rice straw extract. For gibberellic acid, the highest value was recorded in treatment of $100 \%$ soybean. From the results obtained, it could be concluded that, some extracts can be used for reducing the dose of nitrogen fertilizer, reduce the high cost of buying inorganic fertilizers, and thus reduce pollution resulting from the extra-use of these fertilizers and also reduce the cost of agricultural production. However, more studies are needed to determine the exact mechanism(s) that lead to realize improvements.

Keywords: Plant extract, Liquid Fertilizer, agricultural wastes, organic farming, soil
\end{abstract} amendment.

\section{INTRODUCTION}

At present, the farmers used to apply chemical fertilizers in a great quantities to compensate the deficiency of nutrients in soil. Excessive application of mineral fertilizers may affect soil health and sustainable production. This condition certainly not only increases production costs, but also reduces soil fertility, and causes environmental pollution. The adverse effect of inorganic fertilizers on soil and environment is leading scientists to 
examine some alternative such as organic fertilizers. Agricultural wastes such as rice straw, rice hull, peanut husk, corn cob, bagasse, rape seed pomace, castor seed pomace, tree bark, mushroom growth medium waste, and shrimp shell powder are widely used in land reclamation and in the production of horticultural crops. The use of the waste products is one of the corner stones of organic farming. This means returning back to the soil, all manures and plant residues produced on the farm in the best form possible, with minimum loss and maximum stability of nutrients (Vercesi 2000 and Bonanzinga, et al. 2001). Large quantities of agricultural residues wastes are produced each year in Egypt. These include about 20 million tons of crop residues (ElShemy and Aly 1997.). Mismanagement of organic wastes, have impacted public health and environment. These organic wastes are rich in plant nutrients and through proper management such as composting can be used as a soil conditioner, as well as a nutrient source for plants. There is a great variability in the nitrogen availability from different sources of organic fertilizers (Pang and Letey 2000).

Crop cultivation using organic fertilizers has contributed for decomposition of residues, and improving physical and chemical properties of soil that is important for biological development (Galbiattia et al., 2007). The effect of wood ash, sawdust, ground cocoa husk, spent grain and rice bran upon root development, ash content, pod yield and nutrient status and soil fertility for okra was studied by lbukunoluwa (2007), their results showed that the application of plant residues increased the plant nutrition and soil fertility. Aqueous extract of Sargassum wightii when applied as a foliar spray on Zizyphus mauritiana showed an increased yield and quality of fruits (Rama Rao, 1991). The agricultural wastes benefit crop production by improving soil fertility, increasing soil organic matter (Kostov et al. 1995).

The application of plant extracts into the soil has the potential advantage of being economical, ready available and environmentally safe (Zurren and Khan 1984; Maqbool, et al. 1987 and Olabiyi, 2004). Plant extracts of some trees and crop residues have been reported to influence crop growth and yield (Farooq, et. al., 2008; Ahmed and Nimer, 2002; El Atta and Bashir, 1999; Chung and Miller, 1995). Leaf extracts of M. oleifera have been reported to accelerate growth of young plants, strengthen plants, improve resistance to pests and diseases, increase leaf area duration, increase number of roots, produce more and larger fruits and generally increase yield by 20 to 35\% (Fuglie, 2000). Foidl, et al (2001) who reported a general improved crop performance in response to application of leaf extracts of Moringa oleifera.

Organic farming is considered an important factor of the Polish and EU strategy for the development of the agricultural sector and the production of organic fruits is increasing in the last years. However, the limited availability of classical organic fertilizers (i.e. manure) also in not specialized farms, and scarce information about the effects of new kinds of organic fertilizers like plant extracts (Anon, 2007) are serious bottlenecks threatening the future development of the sector. El-Shayeb (2009) declared that all concentration of Aloe vera extract increased fresh and dry weights of flowers of Oenthera biennis. The best response resulted from the highest 
concentration of Aloe (75\%). Tantawy, et al. (2009) stated that foliar application of extracts of cabbage pollen mixed with some nutrients such as $\mathrm{P}, \mathrm{K}$ and $\mathrm{B}$ can promote plant growth and production as well as pod quality of green bean plants. Sunarpi et al. (2010) reported that some liquid fertilizer products made are proven to increase the absorption of nutrients, which can enhance growth, development and production of various species of agricultural crops extracts from Moringa leaves forced beans to germinate early and increased duration to first germination by $100 \%$. Olabiyi et al. (2011) showed that leaf extracts of pawpaw, tobacco and nitta have the potential to suppress the soil nematode population with a resultant enhanced growth and yield of tomato. Kolawolea (2012) stated that the combined application of plant residues with fertilizer improved soil organic carbon, total $\mathrm{N}$, exchangeable $\mathrm{Ca}$ and $\mathrm{Mg}$ compared with application of NPK fertilizer.

The aim of the study intended to:-

1. Evaluation the effects of plant extract from some natural agricultural residues such as rice straw, Bagasse, and soybean meal when applied with or without recommended rate of nitrogen mineral fertilizers on growth parameters, chemical components and yield of wheat and barley plants.

2. Rationalization of using nitrogen fertilizer to reduce pollution resulting from the extra use of these fertilizers.

3. Reduce the high cost of buying inorganic fertilizers and maintain the long term productivity of soils for sustainable agriculture.

\section{MATERIALS AND METHODS}

\section{Preparation of different aqueous extracts from agricultural residues}

Rice strew, bagass (sugarcane waste), and soybean meal were taken as agricultural residues to prepare some aqueous extracts. These agriculture residues were collected and air dried. The well-dried agriculture residues were chopped into about $5 \mathrm{~cm}$ pieces with fodder cutter. On the other hand, each of the dried agricultural residues was prepared as a tea bag form then each bag was individually soaked in liter of tap water for $24 \mathrm{~h}$ at room temperature in the ratio of $50 \mathrm{~g}$ rice straw $/ \mathrm{L}, 100 \mathrm{~g}$ bagasse $/ \mathrm{L}$, and $200 \mathrm{~g}$ Soybean meal/L. The plant water extract was obtained by filtration. These aqueous extracts were used as a fertilizer for wheat and barley plants. Two experiments (pot and field) were carried out at Giza, Agricultural Research Station, during winter season of 2010/2011. 
Hamed, Mervat A. et al.

Table1. Chemical composition of different agricultural solid residues extract

\begin{tabular}{cccc}
\hline \multirow{2}{*}{ Components } & \multicolumn{3}{c}{ Agriculture solid residues extract } \\
\cline { 2 - 4 } & Rice straw & Bagasse & Soybean meal \\
\hline${ }^{*} \mathrm{~T} . \mathrm{N} \%$ & 1.59 & 0.78 & 2.55 \\
\hline $\mathrm{P}(\mathrm{ppm})$ & 210 & 101 & 253 \\
\hline $\mathrm{K}(\mathrm{ppm})$ & 12116 & 1067.5 & 1768.5 \\
${ }^{* *} \mathrm{~S} . \mathrm{NO3}--\%$ & 0.004 & 0.002 & 0.022 \\
${ }^{* *} \mathrm{~S} . \mathrm{NH} 4+\%$ & 0.008 & 0.008 & 0.019 \\
${ }^{* * *} \mathrm{FAA} \%$ & 1.33 & 1.79 & 2.11 \\
Total carbohydrates\% & 5.09 & 31.9 & 4.4 \\
Gibbrelic acid $(\mathrm{ppm})$ & 155.6 & 108.9 & 133.1 \\
Indole acetic acid $(\mathrm{ppm})$ & 1311.0 & 995.0 & 1220.0 \\
\hline
\end{tabular}

*T means: total

${ }^{* *}$ S means: soluble

${ }^{\star \star \star}$ FAA means: free amino acids

\section{Pot experiment:}

A preliminary pot experiment was carried out to test the effect of three aqueous extracts (rice straw, Bagasse, and soyabean meal), and mixture of these extracts on the growth of wheat plants (Triticum diccocum) which grown in sandy soil.

Twenty grains of wheat cultivars (sakha 94) were grown in each pot $(9 \mathrm{~cm}$ diameter) in three replicates in a complete randomize design. The pots were kept at room temperature for seed growth about two months of period, October-November (2010). Shoot length and dry weight at vegetative growth period were recorded. The various aqueous extracts were added for each pot based on available $\mathrm{N}$ in the agriculture residues extract and recommendation of $\mathrm{N}$ fertilizer for wheat. Soils were fertilized with $\mathrm{p}$ and $\mathrm{K}$ with recommended rates. The treatments of this experiment are listed in (Table 2 ).

\section{Table (2): description of the treatments}

\begin{tabular}{|c|c|c|}
\hline treatment & De & tion \\
\hline T1 & $100 \%$ mineral fertilizer & (M) \\
\hline T2 & $100 \%$ Soyabean meal extract & (A) \\
\hline T3 & $100 \%$ Rice strew extract & (B) \\
\hline T4 & $100 \%$ Bagasse & (C) \\
\hline T5 & $100 \%$ mixture of $A+B+C$ & (D) \\
\hline T6 & $50 \% A+50 \% M$ & \\
\hline T7 & $25 \% A+75 \% M$ & \\
\hline T8 & $50 \% \mathrm{~B}+50 \% \mathrm{M}$ & \\
\hline T9 & $25 \% B+75 \% M$ & \\
\hline T10 & $50 \% \mathrm{C}+50 \% \mathrm{M}$ & \\
\hline T11 & $25 \% \mathrm{C}+75 \% \mathrm{M}$ & \\
\hline T12 & $50 \% \mathrm{D}+50 \% \mathrm{M}$ & \\
\hline T13 & $25 \% \mathrm{D}+75 \% \mathrm{M}$ & \\
\hline
\end{tabular}

\section{Field experiment:}

The field experiment was carried out to verifying the effect of the three aqueous extracts on barley plants. Barley grains (Hordeum vulgare) 
were planted in the experimental farm of Agriculture Research Centre (ARC) at El-Giza governorate, Egypt. Field experiment consisted of $4 \mathrm{~m}^{2}(2 \times 2 \mathrm{~m})$ in area plots with three replicates for each plant extract treatment as well as control (mineral fertilizer only). Experiment was designed in a complete randomized block design. Grains of barley were sown in winter growing season (November-April) of 2010/2011. Some Physical and chemical characteristics of the studied soil before planting are presented in Table (3). Soil was fertilized with $\mathrm{P}$ and $\mathrm{K}$ with recommended rates. The various aqueous extracts were added for each plot based on available $N$ in the agriculture residues extract and recommendation of $\mathrm{N}$ fertilizer for barley. During the growth of plants some plants were taken to determine of some plant hormones. The final plant sampling was taken at plant harvesting period. Collected samples were dried at $60^{\circ} \mathrm{C}$ then kept for some analysis.

Table 3. Some physical and chemical properties of the tested soil

\begin{tabular}{|c|c|}
\hline Physical & Value \\
\hline Sand\% & 12.04 \\
\hline Silt \% & 45.45 \\
\hline Clay\% & 42.51 \\
\hline Texture soil & Silty clay \\
\hline \multicolumn{2}{|l|}{ Chemical } \\
\hline $\mathrm{pH}$ (1: 2.5, soil suspension) & 7.85 \\
\hline Organic matter (\%) & 1.42 \\
\hline ECe dS m ${ }^{-1}$, soil paste & 0.65 \\
\hline \multicolumn{2}{|l|}{ Soluble cations (me/L) } \\
\hline $\mathrm{Ca}^{++}$ & 0.41 \\
\hline $\mathrm{Mg}^{++}$ & 0.05 \\
\hline $\mathrm{Mg}^{++}$ & 5.97 \\
\hline $\mathrm{K}^{++}$ & 0.07 \\
\hline \multicolumn{2}{|l|}{ Soluble anions (me/L) } \\
\hline $\mathrm{CO}^{=}$ & - \\
\hline $\mathrm{HCO}^{-}$ & 0.25 \\
\hline $\mathrm{Cl}^{-}$ & 0.09 \\
\hline $\mathrm{SO} 4^{=}$ & 6.16 \\
\hline
\end{tabular}

\section{Analytical methods:}

Some Physical and chemical characteristics of the studied soil was determined according to Page et al., (1982). In plant sample, phosphorus content was determined by vanadomolybdate yellow method spectrophotometrically and K by flame photometer (Jackson, 1973). Total nitrogen was determined by micro-Kjeldahl method according to (AOAC., 1970). Crude protein was calculated by multiplying the values of total nitrogen in 6.25. Indole-3-acetic acid was determined according to the method described by Mahadevan and Chandramohan (1966). Gibberellic acid was extracted and determined in plant tissue according to the method described by (Cho, et al. 1979). Total carbohydrate was extracted according to (Smith, et al. 1964) and determined using spectrophotometer according to (Murphy, 1958). All determinations were performed in triplicate and data represented on dry weight basis as mean values \pm standard deviations. 
Total Yield

At the end of season all plants were harvested and collected per plot and yield per feddan were then calculated.

\section{Economic Evaluation:}

The yield components were calculated and economical analysis performed using the following equation out lined by FAO (2000).

1) Total return $=$ yield $\times$ price $($ grain + straw $)$

2) Net return (NR) = Total return - Total cost of production

3) Investment factor (IF) = Net return (NR) / total cost of production

\section{Statistical Analysis}

All data were statistically analyzed using Costat computer program according to procedures outlined by Snedecor and Cochran (1980).

\section{RESULTS AND DISCUSSION}

\section{Pot experiment}

Vegetative Growth of wheat:

Data in Table (4) illustrate the measured growth parameters of wheat plants as affected by application of some agricultural residues extracts. Shoot length and dry weight were obtained positively responded to apply all the studied agricultural residues extracts. Results indicated that, there is a significantly increased of wheat shoot dry weight with using $25 \%$ mixture of three extracts with $75 \%$ nitrogen mineral fertilizer treatment compared to control treatment. Regarding to the shoot length, the maximum response recorded with the treatment of $100 \%$ mixture of three extracts, while the minimum response was recorded with the treatment of mineral fertilizer only (control treatment). In general most of treatments were manifested high values of shoot length and dry weight than control treatment (mineral nitrogen fertilizer). These means that, all agricultural residual extracts have a positive effect on wheat plant growth.

Table 4. Effect of some agricultural residues extracts on shoot length and dry weight of wheat plant at vegetative growth under pot experiment

\begin{tabular}{|c|c|c|}
\hline Treatment & Shoot length $(\mathrm{cm})$ & Dry weight (g/pot) \\
\hline $\mathrm{T} 1$ & $22.30^{\circ}$ & 0.97 \\
\hline T2 & $27.27^{\mathrm{du}}$ & $1.17^{\mathrm{duc}}$ \\
\hline T3 & 26.75 avc & $0.87^{\mathrm{c}}$ \\
\hline T4 & $23.28^{\text {cu }}$ & $0.87^{\mathrm{c}}$ \\
\hline T5 & $27.83^{d}$ & $1.40^{\mathrm{auc}}$ \\
\hline T6 & $27.57^{\mathrm{du}}$ & $1.27^{\mathrm{anc}}$ \\
\hline T7 & 25.00 ancu & 1.37 anc \\
\hline T8 & $23.87^{\mathrm{veu}}$ & $1.30 \mathrm{anc}$ \\
\hline T9 & 24.25 ancu & $1.37^{\mathrm{auc}}$ \\
\hline T10 & 25.49 ancu & 1.30 anc \\
\hline T11 & 25.78 ancu & $1.50^{\mathrm{av}}$ \\
\hline T12 & 25.34 ancu & $1.13^{\text {auc }}$ \\
\hline T13 & $24.27^{\mathrm{aucu}}$ & $1.63^{\mathrm{d}}$ \\
\hline L.S.D at $0.05 \%$ & 3.936 & 0.5838 \\
\hline
\end{tabular}

Means of each column with different letters are significantly different at $\mathrm{P} \leq 0.05$ 
Field experiment

Vegetative Growth of barley:

Results in Table (5) showed that the highest value of shoot length was recorded in treatment of $100 \%$ rice straw extract and also the same value was recorded in the treatment of mineral fertilizer only compared with the other treatments. The highest value of fresh weight was recorded in treatment of $25 \%$ soybean meal extract with $75 \% \mathrm{~N}$ minerals fertilizer. Also, the treatment of mineral fertilizer was approximately given the same trend compared to the other treatments.

Table 5. Effect of some agricultural residues extracts on shoot length and freshweight of barley plant after two months from sowing under field experiment

\begin{tabular}{ccc}
\hline Treatment & Shoot length (cm/plant) & Fresh weight (g/plant) \\
\hline T1 & $101.0^{\mathrm{a}}$ & $543.7^{\mathrm{ab}}$ \\
T2 & $92.50^{\mathrm{abc}}$ & $357.3^{\mathrm{bcd}}$ \\
T3 & $101.7^{\mathrm{a}}$ & $434.7^{\mathrm{abcd}}$ \\
T4 & $91.77^{\mathrm{abc}}$ & $325.0^{\mathrm{cd}}$ \\
T5 & $85.30^{\mathrm{bcde}}$ & $502.5^{\mathrm{abc}}$ \\
T6 & $75.87^{\mathrm{e}}$ & $264.8^{\mathrm{a}}$ \\
T7 & $88.30^{\mathrm{bcde}}$ & $586.2^{\mathrm{a}}$ \\
T8 & $89.50^{\mathrm{abcd}}$ & $426.3^{\mathrm{abcd}}$ \\
T9 & $79.00^{\mathrm{de}}$ & $429.2^{\mathrm{abcd}}$ \\
T10 & $80.33^{\mathrm{cde}}$ & $508.0^{\mathrm{abc}}$ \\
T11 & $93.10^{\mathrm{ab}}$ & $401.2^{\mathrm{abcd}}$ \\
T12 & $86.30^{\mathrm{bcde}}$ & $459.9^{\mathrm{abcd}}$ \\
T13 & $82.90^{\mathrm{bcde}}$ & $319.3^{\mathrm{cd}}$ \\
\hline LSD & 12.54 & 195.3
\end{tabular}

Means of each column with different letters are significantly different at $\mathrm{P} \leq 0.05$

\section{Grain and straw yield of barley plant:}

Data are shown in Fig. (1) demonstrated that among the extracts tested, $100 \%$ rice straw extract follows with $50 \%$ bagasse with $50 \%$ nitrogen mineral fertilizer were the best effective on yield relative to mineral fertilizer treatment (control). Grain yield reached 1.10 and 1.03-fold that of control, respectively. The results may be due to the presence of some growth regulator such as indole acetic acid and giberllic acid in plant extracts as shown in Table (1). The content of indole acetic acid or giberllic acid in different plant extracts was in the following order: rice straw > soybean meal $>$ bagasse. These results agree with Challen and Hemingway (1966) who stated that the increased yield may be due to the presence promoting substances such as IAA and IBA, gibberellins, cytokinins, micronutrients, vitamins and amino acids in plant extracts. 
Hamed, Mervat A. et al.

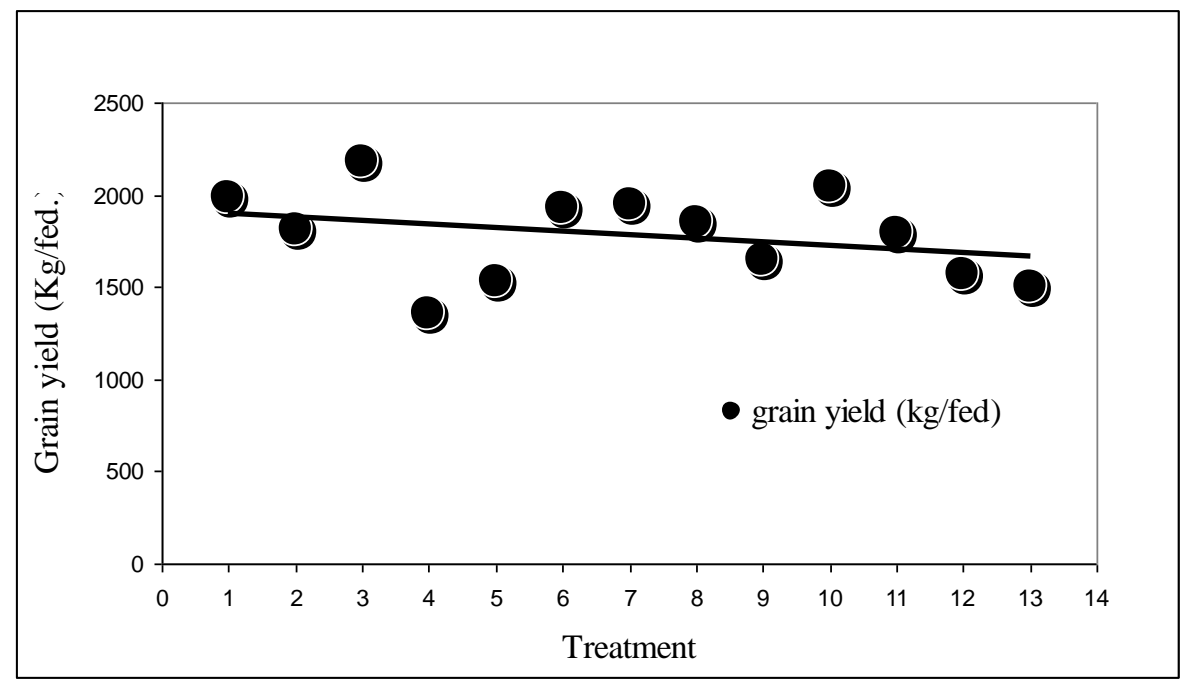

Figure (1): Effect of different agricultural residues extracts on grain yield of barley plant under field experiment

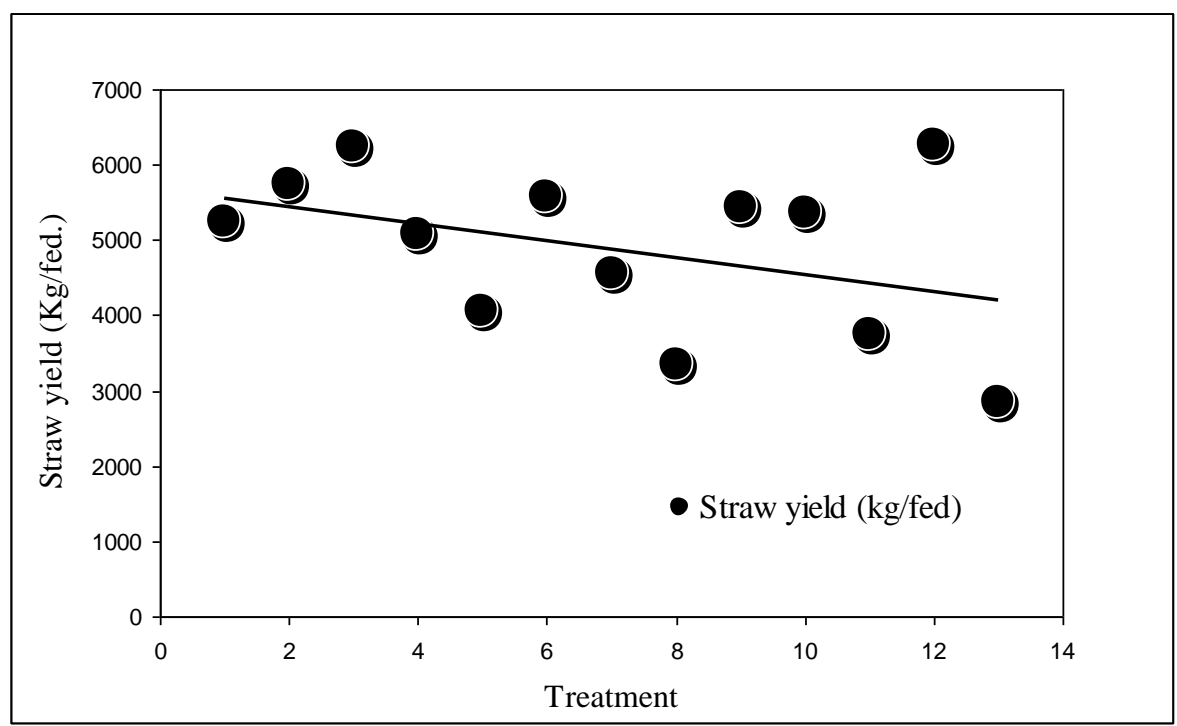

Figure (2): Effect of different agricultural residues extracts on straw yield of barley plant under field experiment

It is worth mentioning that the effect of some treatments on grain yield of barley plants was nearly the same of the effect of mineral fertilizer treatment (control). No significant differences were observed in grain yield between most of treatments and control as shown in Fig. (1). On the other 
hand, the lowest value of grain yield was recorded in $100 \%$ bagasse extract treatment; the decrease percentage reached $32.4 \%$ relative to control. Concerning the straw yield of barley plant, data showed the highest value was recorded at treatments $100 \%$ rice straw and $50 \%$ mixture of different extracts with $50 \%$ nitrogen mineral fertilizer. While the lowest value of straw yield (Fig. 2) was recorded in the treatment of $25 \%$ mixture of different extracts with $75 \%$ nitrogen mineral fertilizer. From this result, it may be concluded that, the combined application of some plant extracts residues with fertilizer may be improved soil organic carbon, total $\mathrm{N}$ compared with application of NPK fertilizer, these results agree with Kolawolea (2012).

\section{Mineral Contents:}

The results are summarized in Table (6) showed the effect of different agricultural residues extracts on mineral content of barley grain under field experiment. There was slightly different in nitrogen percentages as a result of all extract treatments and control. The highest values of nitrogen percent were recorded in $25 \%$ soyabean meal extract with $75 \%$ nitrogen mineral fertilizer followed by $25 \%$ rice straw extract with $75 \%$ nitrogen mineral fertilizer treatment compared to control. These results may be due to the soyabean meal extract contains high amounts of total nitrogen and free amino acids as shown in Table (2). Phosphorus content showed increasing at $25 \%$ mixture of different extract with $75 \%$ nitrogen mineral fertilizer treatment. While the lowest value was recorded in $50 \%$ bagasse extract with $50 \%$ nitrogen mineral fertilizer treatment. No significant effect was observed in other treatment. The highest value of potassium content was recorded in $25 \%$ soyabean meal extract with $50 \%$ nitrogen mineral fertilizer. No significant differences among most of the other treatments compared to control.

Table 6: Effect of different agricultural residues extracts on mineral content of barley plant under field experiment

\begin{tabular}{cccc}
\hline Treatment & $\mathbf{N} \%$ & $\mathbf{P} \%$ & $\mathbf{K} \%$ \\
\hline T1 & $2.010^{\mathrm{c}}$ & $0.320^{\mathrm{bc}}$ & $0.463^{\mathrm{ab}}$ \\
T2 & $2.183^{\mathrm{bc}}$ & $0.296^{\mathrm{bc}}$ & $0.466^{\mathrm{ab}}$ \\
T3 & $2.333^{\mathrm{abc}}$ & $0.340^{\mathrm{bc}}$ & $0.396^{\mathrm{b}}$ \\
T4 & $1.997^{\mathrm{c}}$ & $0.310^{\mathrm{bc}}$ & $0.466^{\mathrm{ab}}$ \\
T5 & $1.990^{\mathrm{c}}$ & $0.357^{\mathrm{ab}}$ & $0.433^{\mathrm{ab}}$ \\
T6 & $2.177^{\mathrm{bc}}$ & $0.300^{\mathrm{bc}}$ & $0.466^{\mathrm{ab}}$ \\
T7 & $2.593^{\mathrm{a}}$ & $0.340^{\mathrm{bc}}$ & $0.500^{\mathrm{a}}$ \\
T8 & $2.133^{\mathrm{bc}}$ & $0.357^{\mathrm{ab}}$ & $0.433^{\mathrm{ab}}$ \\
T9 & $2.400^{\mathrm{ab}}$ & $0.323^{\mathrm{bc}}$ & $0.466^{\mathrm{ab}}$ \\
T10 & $1.990^{\mathrm{c}}$ & $0.247^{\mathrm{c}}$ & $0.400^{\mathrm{b}}$ \\
T11 & $2.023^{\mathrm{c}}$ & $0.317^{\mathrm{bc}}$ & $0.400^{\mathrm{b}}$ \\
T12 & $2.333^{\mathrm{abc}}$ & $0.290^{\mathrm{bc}}$ & $0.433^{\mathrm{ab}}$ \\
T13 & $2.067^{\mathrm{bc}}$ & $0.447^{\mathrm{a}}$ & $0.433^{\mathrm{ab}}$ \\
\hline LSD & 0.3454 & $0.1066^{2}$ & 0.09230 \\
\hline
\end{tabular}

Means of each column with different letters are significantly different at $\mathrm{P} \leq 0.05$ 
Hamed, Mervat A. et al.

\section{Chemical and biochemical parameters of plants: \\ Total carbohydrates and crude protein}

The responses of barely plant to different treatments were obvious from the variations among the values of protein and total carbohydrates (Table 7). The highest value of crude protein was observed in treatment of $25 \%$ soyabean meal with $75 \%$ nitrogen mineral fertilizer followed by $25 \%$ rice straw extract with $75 \%$ nitrogen mineral fertilizer compared to control. The increment \% reached 26.9 and $16.15 \%$ relative to control, respectively. While the lowest value was recoded in treatment of $100 \%$ mixture of different extracts. It is probably due to the presence of growth promoting substances and nutrients in more quantities in the individual extract than in mixture of all extracts that contain some antagonistic elements and substances. No significant effect was observed in between other treatments and control. Data of total carbohydrates\% in seeds of barley showed that the responses of plant to different treatments were varied among the total values of carbohydrate contents. The highest value of total carbohydrate was observed in treatment of $100 \%$ bagasse extract, These results may be due to the bagasse extract which contains high amounts of total carbohydrates as shown in Table (1), followed by $100 \%$ mixture of different extract treatment then $50 \%$ rice straw extract with $50 \%$ nitrogen mineral fertilizer, which reached $1.21,1.14$ and 1.11 fold that of control, respectively. While the lowest value was observed in treatment of $50 \%$ soyabean meal extract compared to control. On the other hand, the values of total carbohydrate contents were the same in the treatments of control, $25 \%$ soyabean with $75 \%$ nitrogen mineral fertilizer and $25 \%$ bagasse with $75 \%$ nitrogen mineral fertilizer. The content of carbohydrates in different plant extracts was in the following order: bagasse $>$ rice straw $>$ soybean meal.

Table 7. Effect of different agricultural residues extracts on carbohydrate and protein $\%$ of barley plant under field experiment

\begin{tabular}{ccc}
\hline Treatment & Protein\% & Total carbohydrates\% \\
\hline T1 & $11.83^{\mathrm{bc}}$ & $65.66^{\mathrm{bcd}}$ \\
T2 & $12.71^{\mathrm{bc}}$ & $56.23^{\mathrm{de}}$ \\
T3 & $13.53^{\mathrm{abc}}$ & $59.13^{\mathrm{de}}$ \\
T4 & $11.62^{\mathrm{bc}}$ & $79.69^{\mathrm{a}}$ \\
T5 & $11.49^{\mathrm{c}}$ & $75.33^{\mathrm{ab}}$ \\
T6 & $12.59^{\mathrm{bc}}$ & $52.54^{\mathrm{e}}$ \\
T7 & $15.02^{\mathrm{a}}$ & $64.39^{\mathrm{bcd}}$ \\
T8 & $12.46^{\mathrm{bc}}$ & $72.98^{\mathrm{abc}}$ \\
T9 & $13.74^{\mathrm{ab}}$ & $58.48^{\mathrm{de}}$ \\
T10 & $11.49^{\mathrm{c}}$ & $62.54^{\mathrm{cde}}$ \\
T11 & $11.70^{\mathrm{bc}}$ & $65.74^{\mathrm{bcd}}$ \\
T12 & $13.39^{\mathrm{bc}}$ & $55.80^{\mathrm{de}}$ \\
T13 & $12.65^{\mathrm{bc}}$ & $55.63^{\mathrm{de}}$ \\
\hline LSD & $2.207^{\mathrm{bc}}$ & 11.68 \\
\hline
\end{tabular}

Means of each column with different letters are significantly different at $P \leq 0.05$ 
Indole acetic acid and gibberillic acid

Data presented in Table (8) illustrate the effect of different treatments on some hormones content of barley leaves that collected after two months of cultivation. There was progressive increment in indole acetic acid and gibrellic acid averages of barely leaves as a result of treated with different agricultural resides extract compared with control. The highest value of IAA was recorded in treatment of $100 \%$ rice straw extract which reached 3.35 fold that of control. For gibrellic acid, the highest value was recorded in treatments of $100 \%$ soyabean and $50 \%$ rice straw with $50 \%$ nitrogen mineral fertilizer which reached 1.69 and 1.45 fold that of control, respectively. It is worth mention that, the values of both hormones in all different extract treatments were recorded the higher values than control treatment. These results may be due to the presence of indole acetic acid and gibrellic acid in all plant extracts as shown in Table (1). The content of indole acetic acid or gibrellic acid in different plant extracts was in the following order: rice straw > soybean meal > bagasse.

Table 8: Effect of different agricultural residues extracts on hormone content of Barley plant under field trial

\begin{tabular}{|c|c|c|}
\hline Treatment & IAA (ppm) & Gibberlic (ppm) \\
\hline $\mathrm{T} 1$ & $6.37^{\dagger}$ & $19.65^{\mathrm{e}}$ \\
\hline T2 & $13.17^{\text {bcd }}$ & $33.20^{\mathrm{a}}$ \\
\hline T3 & $21.40^{\mathrm{a}}$ & $25.10^{\text {bcde }}$ \\
\hline T4 & $16.50^{b}$ & $22.95^{\text {bcde }}$ \\
\hline T5 & $16.15^{b}$ & $20.45^{\mathrm{de}}$ \\
\hline T6 & $13.53^{\mathrm{bcd}}$ & $25.00^{\mathrm{bcd}}$ \\
\hline T7 & $13.40^{\text {bcd }}$ & $26.00^{\text {bcd }}$ \\
\hline T8 & $11.30^{\mathrm{cd}} \mathrm{e}$ & $28.50^{\text {ab }}$ \\
\hline T9 & $10.30^{\mathrm{de}}$ & $20.27^{\mathrm{de}}$ \\
\hline T10 & $13.50^{\mathrm{bcd}}$ & $27.47^{a b c}$ \\
\hline T11 & $15.90^{b}$ & $22.60^{\text {cde }}$ \\
\hline T12 & $14.10^{b c}$ & $22.03^{\text {cde }}$ \\
\hline T13 & $9.40^{\text {ef }}$ & $24.93^{\text {bcde }}$ \\
\hline LSD & 3.404 & 5.864 \\
\hline
\end{tabular}

Means of each column with different letters are significantly different at $\mathrm{P} \leq \mathbf{0 . 0 5}$

From the obtained results, it could be noticed that there is a positive effect of several aqueous extracts on the growth, development and consequently yields of field crops have been proved so far. The best results were obtained with $100 \%$ rice straw extract, $100 \%$ soyabean meal extract followed by $50 \%$ bagasse with $50 \%$ nitrogen mineral fertilizer treatment then $50 \%$ mixture of different extracts with $50 \%$ nitrogen mineral fertilizer treatment compared to mineral fertilizer only (control). Aqueous extracts constitute a source of many substances, valuable from the point of view of plant physiology, which particularly help plants adapt to stressful conditions such as biologically active alginic acids, polyphenols, free amino acids, and particularly natural plant phytohormones. The increased yield may be due to the presence of some growth promoting substances such as IAA and IBA, gibberellins, cytokinins, micronutrients, vitamins and amino acids (Challen 
and Hemingway, 1966). These compounds were able to stimulate growth as a result of enhancement of protein synthesis and cell division, and mobilization of nutrients needing for growth. The nutritional quality of grain such as carbohydrate, protein and minerals also improved under the influence of treatment Zodapea, et al (2009). The increase in protein content in treated plants with residues extracts is in agreement with the results obtained by Kannan and Tamil Selvan, (1990), they attributed the increase in protein content to the absorption of most of the necessary elements by plant.

\section{Economic Evaluation:}

The economic analysis is the ultimate directory to recommend a technology. The results of the economical analysis for this study illustrated in Table (9). It is important to compare total cost of production, total return, and the net return under the different treatments. Total return of barley is based on productivity of grains and straw (Kg/fed.). The cost of production included the cost of tillage, agricultural practices, fertilizers, and pesticides. It is obvious from the results that, generally, all treatments realized reasonable profitability because their investment factor (IF) more than 3 (FAO 2000). The maximum profitable or net return (8544.6 LE) was obtained from the treatment of $100 \%$ rice straw extract followed by the treatment of $50 \%$ bagasse with $50 \%$ mineral nitrogen fertilizer. The data also indicated that the highest investment factor (IF) of 10.4 was recorded with $100 \%$ rice straw extract treatment followed by the treatments of $100 \%$ bagasse extract and $50 \%$ bagasse with $50 \%$ mineral nitrogen fertilizer which had net return (5902.4 and 7297 LE) respectively. These mean that the highest investment factor (IF) does not always give the highest profitable return. Thus, it can be concluded that the treatment of $100 \%$ rice straw extract achieved the highest income for farmers.

Table 9: Economic evaluation of using of plant extracts instead of chemical fertilizer.

\begin{tabular}{ccccccc}
\hline Treatment & $\begin{array}{c}\text { Total } \\
\text { grain yield } \\
\text { (Kg/fed.) }\end{array}$ & $\begin{array}{c}\text { Total straw } \\
\text { yield } \\
\text { (Kg/fed.) }\end{array}$ & $\begin{array}{c}\text { Total cost } \\
\text { of } \\
\text { production }\end{array}$ & $\begin{array}{c}\text { Gross } \\
\text { income } \\
\text { (LE/fed.) }\end{array}$ & $\begin{array}{c}\text { Net } \\
\text { return } \\
\text { (NR) }\end{array}$ & $\begin{array}{c}\text { Investment } \\
\text { factor (IF) }\end{array}$ \\
\hline T1 & 1986 & 5252 & 1244 & 8173.6 & 6879.6 & 5.3 \\
T2 & 1809 & 5752 & 1321 & 8219.6 & 6848.6 & 5.0 \\
T3 & 2184 & 6252 & 775 & 9369.6 & 8544.6 & 10.4 \\
T4 & 1354 & 5073 & 814 & 6766.4 & 5902.4 & 6.8 \\
T5 & 1530 & 4055 & 970.1 & 6304.0 & 5283.9 & 5.2 \\
T6 & 1928 & 5578 & 1282.5 & 8318.4 & 6985.9 & 5.2 \\
T7 & 1948 & 4564 & 1263.3 & 7547.2 & 6233.9 & 4.7 \\
T8 & 1852 & 3338 & 1009.5 & 6374.4 & 5314.9 & 5.0 \\
T9 & 1648 & 5433 & 1126.8 & 7642.4 & 6465.6 & 5.5 \\
T10 & 2042 & 5365 & 1029 & 8376.0 & 7297.0 & 6.8 \\
T11 & 1789 & 3742 & 1136.6 & 6571.6 & 5385.0 & 4.5 \\
T12 & 1567 & 6261 & 1107.1 & 8142.8 & 6985.7 & 6.0 \\
T13 & 1500 & 2857 & 1175.6 & 5285.6 & 4060.0 & 3.3 \\
\hline
\end{tabular}




\section{Conclusion}

It can be concluded from the results obtained from this study that the various aqueous agricultural residues extract application to wheat and barely plants results in an improvement in plant growth and production especially in treatments of $100 \%$ rice straw extract, followed by $50 \%$ bagasse with $50 \%$ nitrogen mineral fertilizer treatment compared to mineral fertilizer only as a control. So, these extracts can be used for reducing the dose of nitrogen fertilizer, and thus reduce pollution resulting from the extra use of these fertilizers. Also these extracts can be used to reduce the high cost of buying inorganic fertilizers and maintain the long term productivity of soils for sustainable agriculture. Therefore, the efforts to maximize the application of nutrients by using extracts of natural products that contain stimulants, is a strategic move to suppress the use of excessive doses of chemical fertilizer. However, more studies are needed to determine the exact mechanism(s) that lead to these improvements.

\section{Acknowledgements}

Thanks are due to Prof. Dr. Somaya Ahmed Hassanein and Prof. Dr. Mostafa Helmy, professor of soil science for providing with information and technical assistance.

\section{REFERENCES}

A.O.A.C., (1970). Official Methods of Analysis. A.O.A.C., Washington, D.C.

Anon, y. (2007). Action Plan for Organic Food and Agriculture in Poland for the years 2007- 2013. Ministry of Agriculture and Rural Development, Warsaw, Poland.

Ahmed, D.M. and Nimer, A.M. (2002). Effects of Acacia senegal (L., Wild) on sandy soils. A case study of El Damokya Forest, Northern Kordofan State. Univ. Khartoum J. Agric. Sci., 10: 106-118.

Bonanzinga, M.; Martellucci, R. and Nardi, G. (2001). The organic viticulture sector in Tuscany. (Bibliographic citation): Informatore Agrario 57: 21, 71-72. CAB Abstracts.

Challen, S.B. and Hemingway, J.C. (1966). Growth of higher plants in response of feeding with seaweed extracts. Proc. Fifth Int. Seaw. Symp. 359-367.

Chung, M. and Miller, D.A. (1995). Allelophathic influence of nine forage grasses on germination and seedling growth of alfalfa. Agron. J., 87: 767-782.

Cho K. Y.; Sakurai. A. and Kamiya, Y. (1979). Effects of the new plant growth retardants of quaternary ammonium iodides on gibberellin biosynthesis in Gibberella fujikuroi. Plant Cell Physiol 20: 25-81.

El Atta, H.A. and Bashir, I.A. (1999). Adverse effects of Eucalyptus camaldulensis (Dehn) leaf extract on germination and seedling growth of wheat. University Khartoum J. Agric. Sci., 7: 70-79.

El-Shemy, S. and Aly, B. (1997). Report on agriculture wastes in Egypt. (In. El-Galaa A (Ed.) Organic Agriculture, 308. 
El-Shayeb, N.S.A., (2009). Physiological Studies on Oenothera biennis (BioFertilizer and Plant Extracts). Ph.D. Thesis, Hort. Dept., Fac. Agric., Benha Univ. Egypt, pp: 86-204.

Farooq, M.; Jabran, K.; Rehman, H. and Hussain, M (2008). Allelopathic effects of rice on seedling development in wheat, oat, barley and berseem. Allelopath. J., 22: 385-390.

FAO (2000). Fertilizer Demonstrations. A pocket guide for extension officers. Fourth edition. Food and Agriculture Organization of the United Nation. International Fertilizer Industry Association Rome.

Foidl, N.; Makkar, H.P.S. and Becker, K. (2001). The potential of Moringa oleifera for agricultural and industrial uses, pp 45-76, In: The Miracle Tree: The Multiple Attributes of Moringa (Ed) Lowell J. Fuglie, CTA, Wageningen.

Fuglie, L.J (2000). The Miracle Tree: Moringa oleifera: Natural Nutrition for the Tropics. The Miracle Tree: The Multiple Attributes of Moringa, 172.

Galbiattia, J.A.; Cavalcantea, I.H.L.; Ribeiroa, A.G. and Pissarraa, T.C.T. (2007). Nitrate and sodium contents on lettuce and drained water as function of fertilizing and irrigation water quality in Brazil. Int. J. Plant Prod. 1: 205-214.

Ibukunoluwa, E. M. (2007). Use of plant residues for improving soil fertility, pod nutrients, root growth and pod weight of okra (Abelmoschus esculentum) L. Bioresource Technology, 98 (11): 2057-2064.

Jackson, M.L. (1973). "Soil Chemical Analysis". Prentice Hall of India Pvt. Ltd., New Delhi.

Kannan, L. and Tamil Selvan, C. (1990). Effect of seaweed manure on Vigna radiata L. (green gram). In: Perspective in Phycology. Porf M.O.P. lyengar Centenary Celebration Volume, (V. N. Raja Rao, Ed.) Today and Tomorrow's Printers and Publishers, New Delhi: 427-430.

Kolawolea, G. O. (2012). Effects of leguminous plant residues and NPK fertilizer application on the performance of yam (Dioscorea rotundata 'c.v.' ewuru) in south-western Nigeria. Archives of Agronomy and Soil Science, 31 (1): 1-12.

Kostov, O.; Tzvetkov, Y.; Kaloianova.; N. and Van-Cleemput, O. (1995). Cucumber cultivation on some wastes during their aerobic composting. Bioresource Technology, 53(3): 237-242.

Mahadevan, A. and Chandramohan, D. (1966). Auxin production by the rice leaf blight fungus, Helminthosporium oryzae and other Helminthosporium. Ind Phylopath Soc Symp Bull. 3: 91-96.

Maqbool, M.A., Hashmi, S.and Ghaffar, A. (1987). Effect of latex extracts from Euphorbia caducifola and Calotropis procera on root knot nematode Meloidogyne incognita infesting tomato and egg plant. Pakistan J. Nematol., 5: 43-48.

Murphy, R. P. (1958). Extraction of plant samples and the determination of total soluble carbohydrates. J. Sci. Food Agric. 9, 714-717.

Olabiyi, T.I., (2004). Assessment of the nematicidal properties of extracts from Tagetes erecta, Ocimum gratissimum, Hyptis suaveolens and Crotalaria retusa. Ph. D Thesis submitted to the Department of Crop Production, University of Ilorin, Nigeria, 177. 
Olabiyi, T.I.; Abolusoro, S.A. and Oyedunmade, E.E.A. (2011) Suppression of Nematode Pests of Tomato withbAqueous Leaf Extracts of Nitta, Tobacco and Pawpaw. American-Eurasian Journal of Agronomy, 4 (2): 23-27.

Page, A.L.; Miller, R.H. and Keeney, D.R. (1982). Methods of Soil Analysis. II: Chemical and Microbiological Properties, 2nd ed.Am.Soc.Agron.Inc; Soil. Soil Sci Soc. Am. Inc, Madison, Wisconsin U.S.A.

Pang, X. P. and Letey, J. (2000). Organic farming: challenge of timing nitrogen availability to crop nitrogen requirements. Soil Sci. Soc. Am. J. 64: 247-253.

Rama Rao, K. (1991). Effect of seaweed extract on Zizyphus mauratiana. Lamk., Journal of Indian Botanical Society, 71: 19-21.

Smith, D.; Paulsen, G.M. and Raguse, C.A. (1964). Extraction of total available carbohydrates from grass and legume tissue. Plant Physiol. 39: $960-962$.

Snedecor, G.W. and Cochran, W.G. (1980). Statistical Method. 7th Ed., lowa State Univ. Press, Ames, lowa, USA.

Sunarpi, A.; Jupri, R.; Kurnianingsih, N.; Indah, J. and Aluh, N. (2010). Effect of seaweed extracts on growth and yield of rice plants. Bioscience 2 (2): 73-77.

Tantawy, A.S.; Abdel-Mawgoud, A.M.R.; Habib, A.M. and Magda, M. (2009). Growth, Productivity and Pod Quality Responses of Green Bean Plants Phaseolus vulgaris to Foliar Application of Nutrients and Pollen Extracts. Research Journal of Agriculture and Biological Sciences, 5(6): 1032-1038.

Vercesi, A., (2000). Soil and foliar applied organic fertilizer in viticulture. Information Agrario., 56(6): 83- 89.

Zodapea, S.T.; Mukherjeea, S.; Reddya, M.P.; and Chaudharya, D.R. (2009). Effect of Kappaphycus alvarezii (Doty) Doty ex silva. extract on grain quality, yield and some yield components of wheat (Triticum aestivum L.). International Journal of Plant Production 3 (2): 97-101.

Zurren, S. and Khan, M.I. (1984). Nematicidal activity in some plant lattices. Pakistan of J. Nematol., 2: 69-77. 
Hamed, Mervat A. et al.

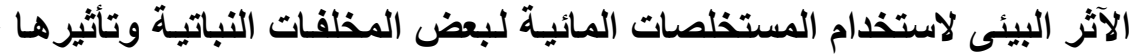

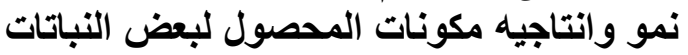

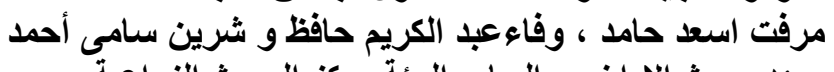

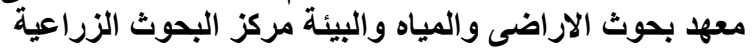

هناك حاجة ماسة لتكثيف الإنتاج الزر اعي في مصر و هذا بنطلب استهلاك كميات كبيرة

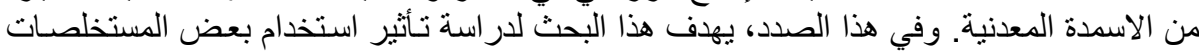

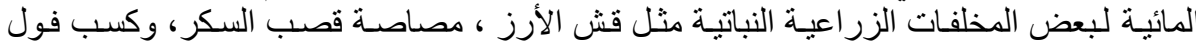

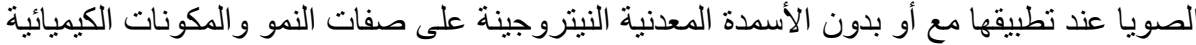

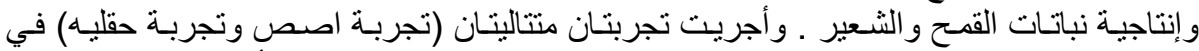

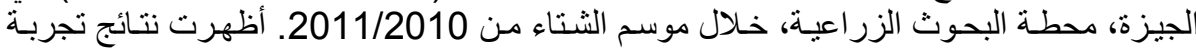

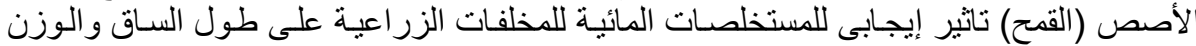

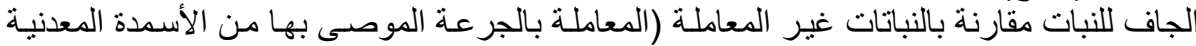

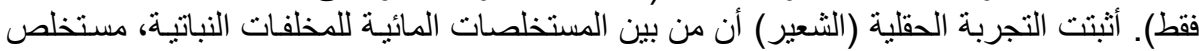

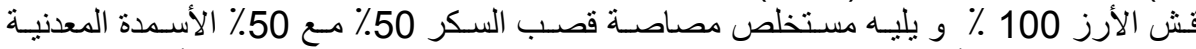

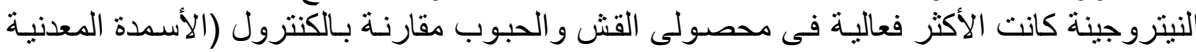

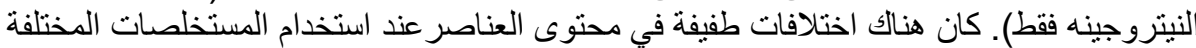

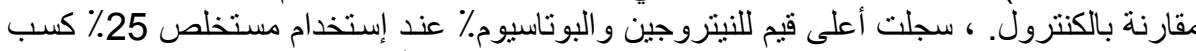

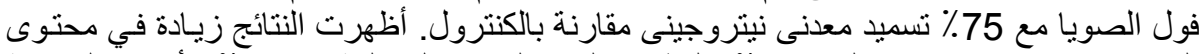

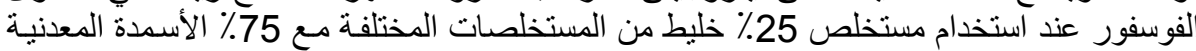

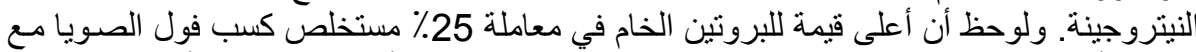

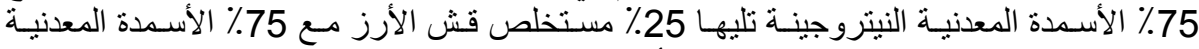

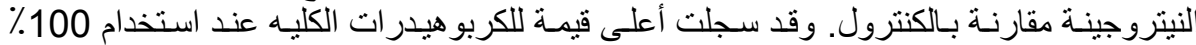

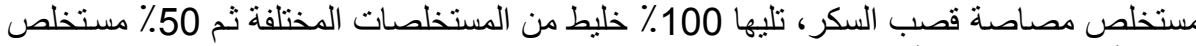

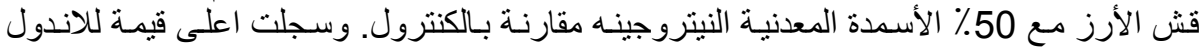

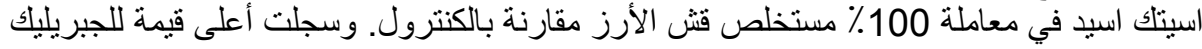

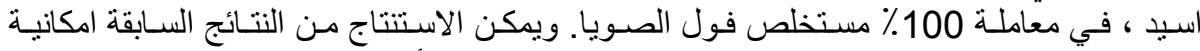

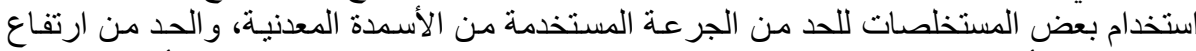

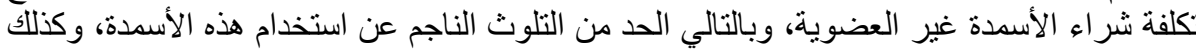

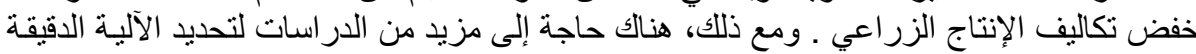
التي تؤدي إلى هذه التحسينات.

كلية الزراعة - جامعة المنصورة

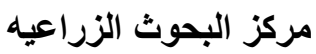

قام بتدكيم البحث

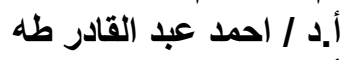

أ.د / أد / سميه اعمد حسانين 